\title{
調査・設計等分野における国土交通省直轄事業 の総合評価落札方式に関する一考察
}

\author{
吉田 純土 1 - 森田 康夫 2 - 大谷 悟 3 - 南 昌宏 4 - 小宮 朋弓 5 \\ 1正会員 国土交通省国土技術政策総合研究所（テ305-0804 茨城県つくば市旭1） \\ E-mail: yoshida-j23j@nilim.go.jp \\ 2正会員国土交通省国土技術政策総合研究所（†305-0804 茨城県つくば市旭 1 ) \\ E-mail: morita-y92tc@nilim.go.jp \\ 3正会員 国土交通省近畿地方整備局猪名川河川事務所（干563-0027大阪府池田市上池田2-2-39） \\ E-mail: ootani-s86wk@kkr.mlit.go.jp \\ 4非会員＼cjkstart国土交通省国土技術政策総合研究所（テ305-0804 茨城県つくば市旭1） \\ E-mail: minami-m925a@nilim.go.jp \\ 5正会員 一般財団法人国土技術研究センター（†105-0001＼cjkstart東京都港区虎ノ門3-12-1） \\ E-mail: t.komiya@jice.or.jp
}

\begin{abstract}
国土交通省直轄事業の調査・設計等業務においては，総合評価落札方式が導入されて以来，各種の低入 札対策の効果もあり，低入札落札は著しく減少した。その一方で，平均落札率はこの 2 亿年において $82 \%$ 付近を横ばいで推移し, 入札価格が調査基準価格近傍に集中する傾向が強まっている. これは, 技術力に おいて優位な参加者が，技術力の優位性を入札価格に十分に反映させていないことが原因であるものと考 えられる. 過度な価格競争は，短期的な企業の利潤に結びつきにくい人材育成や技術開発に要する費用の 削減を促し, 長期的には建設業全体の技術力低下を招くことが懸念される。こうした状況を踏まえ, 本研 究では, 総合評価落札方式の実施状況を分析するとともに, 受注者の聞き取りを通じて明らかになった評 価方法の課題について検討した。
\end{abstract}

Key Words : consultant engineering, bidding system, Quality and Cost Based Selection (QCBS), low price bidding , evaluation approach about quality and price

\section{1. はじめに}

国土交通省等が実施する公共工事や調査・設計等業務 の入札・契約制度において，従前は，随意契約を除き， 指名競争入札による価格競争が落札者を決定する方法と して一般的であった。しかしながら，入札手続きの透明 性，競争性の確保の観点から，平成6年から一定規模以 上の業務に対して，公募型プロポーザル方式や公募型競 争入札方式が導入されるようになった，さらには，平成 11年度に価格に加えて技術力により落札者を決定する総 合評価落札方式が公共工事に導入されて以来，順次，総 合評価落札方式の適用範囲は拡大され，平成19年度に調 查・設計等業務においても総合評価落札方式が試行され， 平成20年度に本格導入された。

導入当初において, 総合評価落札方式においても低入 札落札が多発していたが，平成22年度以降，調查基準価
格を下回る入札に対して履行確実性評価が実施されるこ とにより, 大幅に低入札落札が減少した.

しかしながら，入札価格の詳細を見ると，この2〜3年 において平均落札率・平均入札率は，82\%付近を横ばい で推移し，多くの入札が調查基準価格の直上で行われ， 依然として価格を強く意識した入札が行われているよう である．この原因として，優れた技術力を有する入札参 加者が，その技術力の優位性を入札価格へ十分に反映さ せていないことが考えられる.

総合評価落札方式は，価格と技術力を総合的に評価し， 優れた技術力を有する業者を選定し, 成果品の品質確保 や調査・設計等分野全体の技術力向上を目指寸ものであ る. 技術力を有する業者が，その技術力に見合う適切な 対価を得ず，仮に，そのことによる利潤の減少分を人材 育成や技術開発等に要する費用で補おうとすれば，長期 的には, 品質確保等の総合評価落札方式本来の目的を達 
成できなくなる恐れもある，これらを踏まえると，現行 の総合評価落札方式における価格と技術の評価のあり方 について，今一度，検証する必要があるものと考えられ る.

そこで，本稿は，2.において，総合評価落札方式の実 施状況について概観したうえで, 総合評価落札方式にお いて調査基準価格近傍に入札が集中している現状につい て概説する. 3.においては, 受注者聞き取り調査の結果 から, 調查基準価格近傍に入札が集中寸る原因が技術点 の差が小さいことにある可能性を指摘し，4.において，

入札・契約データから各入札における技術点差の分布状 況を示し, 評価等の課題や今後のあり方について考察す る.

なお，本研究の分析対象は，国土交通省地方整備局と 北海道開発局（以下，地方整備局等という）が実施した 調査・設計等業務（土木コンサルタント業務，測量業務， 地質調查業務等のうち空港・港湾関係業務，農業関係業 務を除いたもの）における業務としている．分析にあた って, 入札額, 評価点, 予定価格等の入札データは, 各 地方整備局等HPや入札情報サービス等から収集した。

\section{2. 総合評価落札方式の実施状況}

\section{（1） 総合評価落札方式の適用状況}

\section{a) 結果}

各地方整備局等が実施した調查・設計等業務について, 全契約方式の実施件数に対する各方式の実施件数の割合 を図-1に示す，総合評価落札方式の適用率は，平成19年 の試行的導入時の $0.1 \%$, 平成20年度の本格導入時の $2.5 \%$ から着実に増加し，平成23年度には41.8\%まで達してい る。一方で価格競争方式の適用率は，平成19年度の 52.3\%から35.7\%まで咸少している.

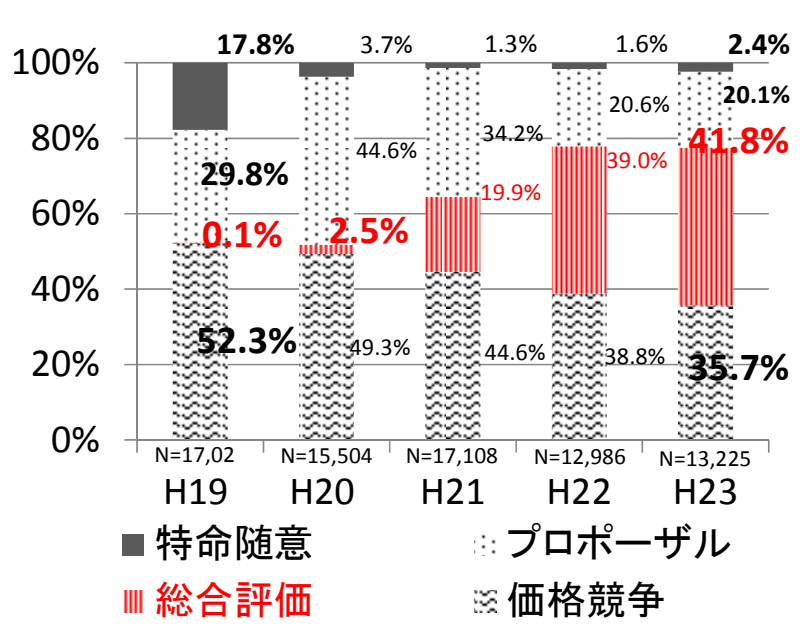

図-1 契約方式別発注件数割合の推移)

\section{b) 考察}

上記における契約方式別の適用率の増減は，価格競争 方式で実施していた業務の多くが総合評価落札方式に移 行したためであると考えられる，なお，プロポーザル方 式の適用率の減少は, 近年の限られた予算の中で整備効 果を早期に発現させるため, 完成・供用間近の事業にお ける詳細設計や用地測量調查等（総合評価落札方式で害 施されることが多い）が優先され，長期構想・計画業務 等（技術的難易度が高く、プロポーザル方式で実施され ることが多い）が減少したことが一因であると考えられ $ろ^{3)}$.

\section{（2）総合評価落札方式の配点比率の適用状況 \\ a) 結果}

調査・設計等業務の総合評価落札方式においては, 評 価方法として除算方式（技術点を価格点で除して評価值 を算出するもの）を採用する公共工事と異なり，加算方 式を採用している. 加算方式は，入札価格に応じて評価 した価格点に，入札者の業務実績や技術提案内容等を評 価した技術点を加えることによって評価值を算出するも のであり, 業務内容に応じて価格点と技術点の配分率

(価格点：技術点）を $1 ： 1 、 1 ： 2 、 1 ： 3$ と設定す ることができる. 平成 21 年度から平成 23 年度までの調 查・設計等分野における総合評価落札方式の各配点比率 の適用状況について図-2 に示寸１：1の適用率は平 成 21 年度の $36.4 \%$ 加平成 23 年度の $43.7 \%$ 一と増加し た一方で，1：2 は 58.5\%から 55.0\%へ，1：3は 5.1\% から $1.3 \%$ へと減少した。

業種別で見た場合, 測量業務における 1：1の適用率 が86.8\%（平成23年度）と著しく高く，1：3 の適用率 は土木コンサルタント業務において $2.1 \%$ と最も高い。し かしながら，土木コンサルタント業務における $1 ： 3$ の 適用率は平成21年度の7.7\%から平成23年度の $2.1 \%$ へ急 減している.

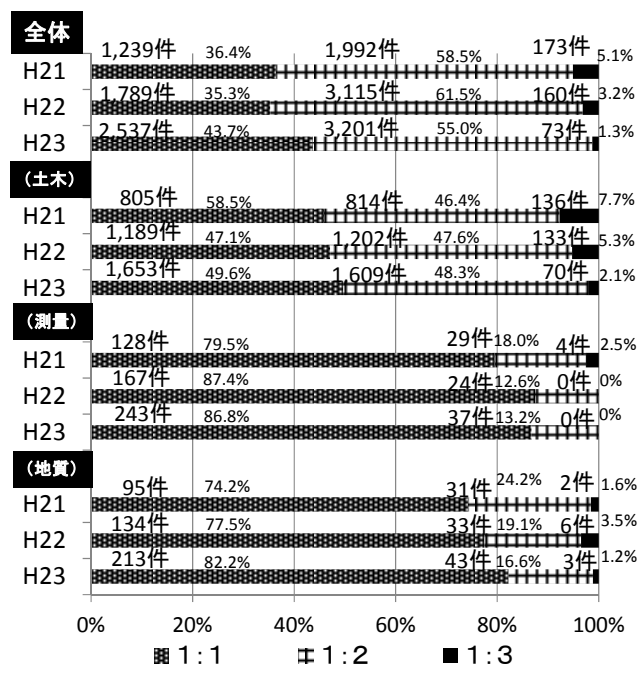

図-2 配点比率別発注件数の推移 ${ }^{2}$ 


\section{b) 考察}

平成21〜 23年度の $1 ： 1$ による発注件数の増加は, 価格競争方式からの移行により，技術的難易度の比較的 低い業務も総合評価落札方式で実施されるようになった ためであると推察される。一方，1：3における発注件 数の減少は, プロポーザル方式による発注件数の減少と 同様に，事業量の減少に伴い，技術的難易度の比較的高 い業務が減少したことが一因であると考えられる.

「調査・設計等業務に関する入札・契約の実施状況」 2)によれば，技術点の配点比率が高いほど業務成績表定 点が良好になる傾向がある.

また，海外に目を向けると，米国においては多くの発 注機関が公告後に技術的に最も優れた建設コンサルタン 卜を選定し交渉の上で契約するQBS（Quality Based Selection）方式を強く推奨し，欧州においてはQCBS（Quality and Cost Based Selection System) が主流であるものの，関 係機関が交渉方式の適用拡大や価格点比率を $20 \%$ 以下に すること等を求めている. 4 )

調査・設計等業務の成果は事業全体のリスクやライフ サイクルコストに多大な影響を及ぼす、調査・設計等業 務における費用削減が，事業全体のコストを増大させる ことがないよう, 成果品の品質確保や調査・設計等分野
における技術力向上を目指寸観点からは，より技術力を 重視した $1 ： 2 ， 1 ： 3$ の普及が望まれる.

\section{（3）低入札落札の発生状況}

a) 結果

地方整備局等が実施した調査・設計等業務について総 合評価落札方式と価格競争方式それぞれの低入札落札発 生率を図-3に，低入札落札件数を表-1に示す。この図は， 平成23年度時点で履行確実性評価の対象範囲である予定 価格が1000万円を超える業務と対象範囲外の予定価格が 1000万円以下の業務に分けて示している. なお，国土交 通省の低入札価格調査制度は，予定価格が1000万円を超 える業務を対象としているため，本研究において「低入 札」とは，（1）予定価格が1000万円超の業務について は低入札価格調査制度における調査基準価格を下回る入 札，（2）予定価格が1000万円以下の業務については予 定価格の75\%以下の入札と定義した. 予定価格が1000万 円を超える総合評価落札方式においては，低入札落札発 生率が平成20年度の39.1\%から平成23年度の0.7\% 几と激 減している. 一方で，価格競争方式と予定価格が1000万 円以下の総合評価落札方式では，依然として20\%以上の 高い低入札落札発生率となっている.
予定価格が1000万円を超える業務

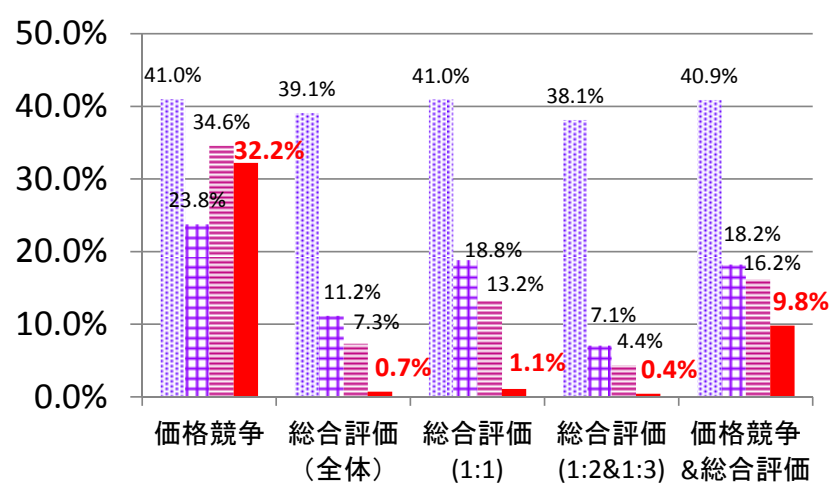

予定価格1000万円以下の業務

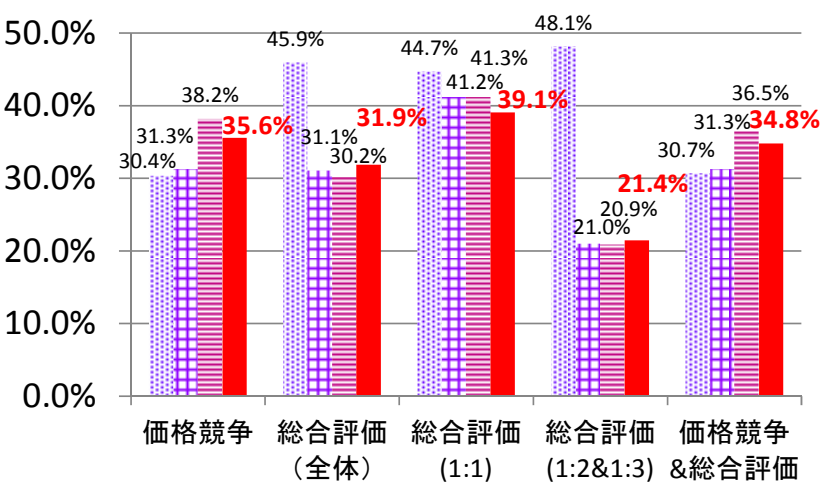

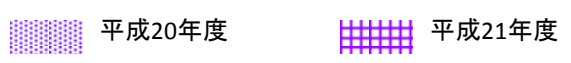

平成22年度

平成23年度

図-3＼cjkstart調達方式別低入札発生率2)

表-1 調達方式別低入札発生件数2)

\begin{tabular}{|c|c|r|r|r|r|r|}
\hline \multicolumn{2}{|c|}{} & 価格競争 & $\begin{array}{c}\text { 総合評価 } \\
\text { (全体) }\end{array}$ & $\begin{array}{c}\text { 総合評価 } \\
(1: 1)\end{array}$ & $\begin{array}{c}\text { 総合評価 } \\
(1: 2 \& 1: 3)\end{array}$ & $\begin{array}{c}\text { 価格競争 } \\
\& \\
\text { 総合評価 }\end{array}$ \\
\hline \multirow{2}{*}{ H23年度 } & 対象業務 & 2,061 & 5,051 & 2,089 & 2,962 & 7,112 \\
\cline { 2 - 8 } & 低入札落札 & 664 & 36 & 23 & 13 & 700 \\
\hline \multirow{2}{*}{$\mathrm{H} 22$ 年度 } & 対象業務 & 2,046 & 4,261 & 1,425 & 2,836 & 6,307 \\
\cline { 2 - 8 } & 低入札落札 & 707 & 312 & 188 & 124 & 1,019 \\
\hline \multirow{2}{*}{$\mathrm{H} 21$ 年度 } & 対象業務 & 3,721 & 2,930 & 1,019 & 1,911 & 6,651 \\
\cline { 2 - 8 } & 低入札落札 & 884 & 327 & 192 & 135 & 1,211 \\
\hline \multirow{2}{*}{$\mathrm{H} 20$ 年度 } & 対象業務 & 3,995 & 307 & 105 & 202 & 4,302 \\
\cline { 2 - 8 } & 低入札落札 & 1,638 & 120 & 43 & 77 & 1,758 \\
\hline
\end{tabular}

\begin{tabular}{|c|c|r|r|r|r|r|}
\hline \multicolumn{2}{|c|}{} & 価格競争 & $\begin{array}{c}\text { 総合評価 } \\
\text { (全体 })\end{array}$ & $\begin{array}{l}\text { 総合評価 } \\
(1: 1)\end{array}$ & $\begin{array}{l}\text { 総合評価 } \\
(1: 2 \& 1: 3)\end{array}$ & $\begin{array}{c}\text { 価格競争 } \\
\begin{array}{c}\text { \& } \\
\text { 総合評価 }\end{array}\end{array}$ \\
\hline \multirow{2}{*}{ H23年度 } & 対象業務 & 2,886 & 756 & 448 & 308 & 3,642 \\
\cline { 2 - 8 } & 低入札落札 & 1,026 & 241 & 175 & 66 & 1,267 \\
\hline \multirow{2}{*}{ H22年度 } & 対象業務 & 2,994 & 799 & 363 & 436 & 3,793 \\
\cline { 2 - 8 } & 低入札落札 & 1,143 & 241 & 150 & 91 & 1,384 \\
\hline \multirow{2}{*}{ H21年度 } & 対象業務 & 3,479 & 409 & 204 & 205 & 3,888 \\
\cline { 2 - 8 } & 低入札落札 & 1,088 & 127 & 84 & 43 & 1,215 \\
\hline \multirow{2}{*}{ H20年度 } & 対象業務 & 3,647 & 74 & 47 & 27 & 3,721 \\
\cline { 2 - 8 } & 低入札落札 & 1,107 & 34 & 21 & 13 & 1,141 \\
\hline
\end{tabular}




\section{b) 考察}

総合評価落札方式においては, 成果品の品質確保を図 るために，予定価格が一定額を超える業務に対して履行 確実性評価を導入している。履行確実性評価とは, 調査 基準価格を下回った場合に, 総合評価点を構成する価格 評価点と技術評価点のうち，技術評価点の技術提案に関 わる部分について, 履行確実性審査の結果に応じて 0.0 から1.0までの一定の数值を乗じるものであり, 調査基 準価格を下回り履行確実性審査が実施された案件におけ る落札件数は非常に少ない. 平成22年度に履行確実性評 価の試行を実施後, 低入札落札発生率は減少傾向にあり, 履行確実性評価の対象業務を予定価格が2000万円を超え る業務から1000万円を超える業務に拡大した後の平成23 年度には，予定価格が1000万円を超える総合評価落札方 式においてほぼ低入札落札が発生しない状態となり，履 行確実性評価の導入が奏効したものと考えられる．ただ し, 上述の低入札落札発生率には, 履行確実性評価を導 入している業務において調査基準価格を下回り，途中で 入札を辞退したケースが含まれない.このようなケース が履行確実性評価実施業務全体の2割弱発生している1 ${ }^{1)}$ め, 今後の辞退者の動向と履行確実性審査の実施状況に 注意する必要がある.

なお，平成20年度から平成21年度にかけて，総合評価 落札方式全体で低入札落札発生率の大幅な減少が見られ るが，これは価格競争から総合評価落札方式一の切替の 過渡期において入札者の入札行動が変化したことが大き な要因であると推察される.

一方で，価格競争方式と予定価格が1000万円以下の総 合評価落札方式については，一部の地方整備局において 予定価格1000万円以下の業務に対しても調査基準価格に 相当する価格の設定等の対策が実施されているものの, 全国的な低入札対策が実施されていないため, 依然とし て低入札落札が多発しているものと考えられる.

\section{（4）総合評価落札方式における入札金額の状況 a) 結果}

調查・設計等業務において地方整備局等が実施した予 定価格が1000万円を超える業務の総合評価落札方式につ いて, 落札率・入札率（落札額・入札額を予定価格で除 した值）毎の業務件数分布の推移を図-4に示寸．落札率 は, 調査基準価格が設定されている80\%付近に集中する 傾向があることが分かる．調査基準価格は業務によって その值が異なるため, 各業務の落札額・入札額を各業務 の調査基準価格で除した值を「調査基準価格率」と定義 し，1ポイントの幅の各「調査基準価格率」帯における 落札件数 - 入札件数の当該年度における全落札件数 - 全 入札件数に対する割合を各調查基準価格率帯における落
札・入札の「出現頻度」とし，この調査基準価格率帯と 出現頻度の関係を図一七に表した。落札・入札ともに調査 基準価格率100\% 105\%付近において出現頻度が年々高 くなる一方で，調查基準価格率100\%未満の分布が大き く減少していることが分かる. ここで, 調査基準価格率 100\%以上 $105 \%$ 未満の範囲における落札・入札の出現頻 度の累計值を表-2に整理した. 落札・入札ともに年々こ の範囲の出現頻度が高まり, 平成23年度は, 落札件数・ 入札件数の半数以上が調査基準価格率 $100 \%$ 以上 $105 \%$ 未 満に集中していることが分かる.

\section{b) 考察}

調査基準価格を下回る落札・入札が著しく減少してい る理由としては, 先述の履行確実性評価の導入とその適 用範囲の拡大が考えられる. 一方で, 落札と入札が調査 基準価格近傍の調查基準価格率100\%以上105\%未満に集 中している点については，入札者が調査基準価格を強く 意識していることが原因であると考えられる．総合評価 落札方式が価格に加えて技術力により落札者を決定する 入札方式であるにもかかわらず，調査基準価格を意識し た入札行動をする理由としては，技術力を有する入札者 がその技術力を入札価格に十分に反映できないことが考 えられる. 以下の章においては，受注者聞き取り調査の 結果をもとに, 調查基準価格近傍に入札がおこなわれる 原因について考察する.

\section{3. 総合評価落札方式に関する受注者聞き取り調 査の結果}

\section{(1) 聞き取り調査の概要}

総合評価落札方式において，調査基準価格近傍に入札 が集中する原因について把握するために，受注者に聞き 取り調査を行った。聞き取り調査は，平成24年8月から 平成25年2月にかけて, 受注者となる建設コンサルタン 卜等で構成される団体（（一社）建設コンサルタンツ協 会, （一社）全国建設コンサルタント業協会連合会,

（一社）全国測量設計業協会連合会）に所属する会員企 業の代表者延べ65名に対して延べ10回にわたり実施した. 聞き取り調查の項目は，「（1）総合評洒落札方式にお いて調査基準価格近傍で入札する理由」，「（2）総合 評価落札方式の評価方法として望まれるもの」である.

\section{(2) 聞き取り調査の結果}

聞き取り調査の結果を表-3 に整理した。調査基準価 格近傍で入札する動機として，過去の入札において，技 術点 1 位が複数存在すること, 各参加者の技術点が僅差 であることを挙げている例が多かった。これに関して受 注者は, 技術提案書等の評価においてより点数差が開く 
評価方法をとることや，価格と技術に関する配点比率に

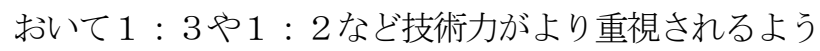
な評価方法をとることを求めている，その一方で，技術
点の予想が困難であることや入札する時点で他の入札者 との技術点差が不明であることから, 調査基準価格近傍 に入札せざるを得ないとの意見もある.

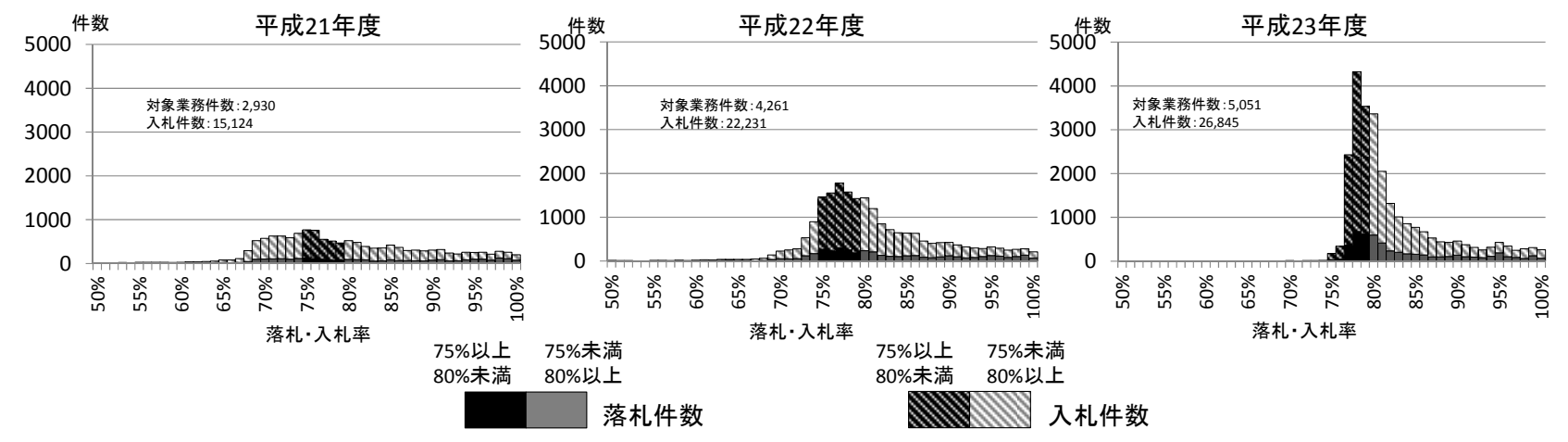

図-4 落札率 $\cdot$ 入札率別落札 $\cdot$ 入札件数 ${ }^{1)}$
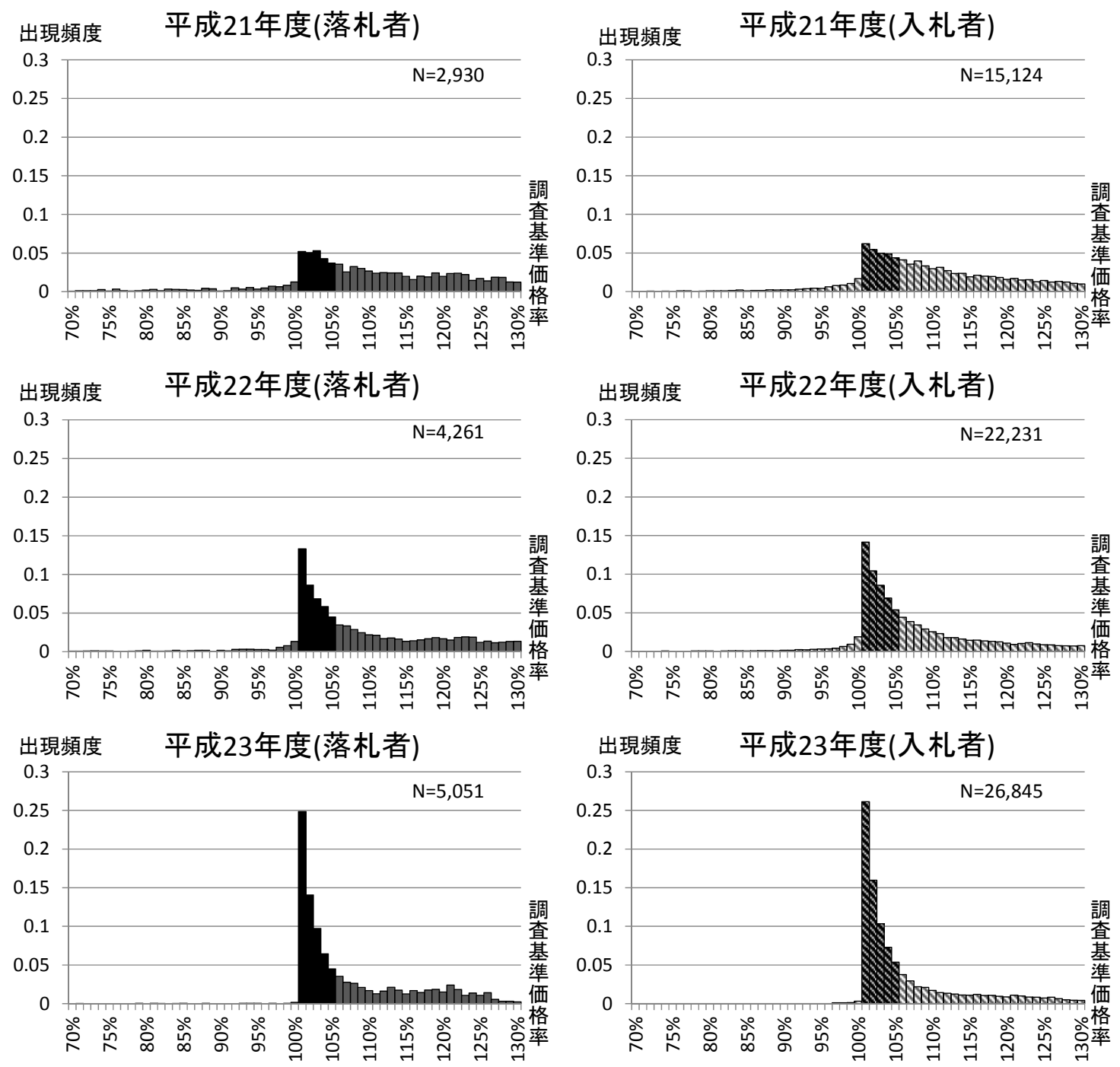

図-5 調査基準価格率別出現頻度 ${ }^{1)}$ 
表-2 調査基準価格率 100\%以上 105\%未満における出現頻度 ${ }^{1)}$

\begin{tabular}{|c|r|r|r|}
\hline & 平成21年度 & 平成22年度 & 平成23年度 \\
\hline 落札 & 0.211 & 0.359 & 0.553 \\
\hline 入札 & 0.231 & 0.420 & 0.600 \\
\hline
\end{tabular}

また，比較的規模の小さい地域コンサルタント等から は，直轄事業の業務実績・表彰に関する評価において不 利な場合，調査基準価格の直上で入札することにより価 格面での優位性を確保すようとするとの意見が聞かれた。 これに関連して，技術点において業務成績や表彰の既定 の評価よりも技術提案書の評価を重視することや，手持 ち業務の受注額・件数を技術点に加味することを望む意 見があった。

さらに，先述の履行確実性評価の導入後は，低入札を 行った場合において，第三者照査の設置義務等のペナル ティを負いながら業務を受注することなく，入札の途中 段階において入札を辞退することが可能となったため, 調査基準価格近傍に価格を設定しやすくなったとの意見 もあつた。

\section{(3) 考察}

聞き取り調査においては，各参加者の技術点の差が小 さいことや技術点が予測不能であるために調査基準価格 近傍入入札するとの意見が多かった．優れた技術提案書 を作成した場合，その過程において，一定の提案書作成 コストを要しているため，他社と比較してどの程度技術 点を獲得できるか予測が困難な状況下では，そのコスト を少しでも確実に回収しようとし，価格競争を誘発して いるものと考えられる．競争者間における技術点差の状 況については，次章以降，入札データの結果をもとに詳 細に考察する.

競争者間における技術点の相対的な評価值が不明であ ることへの対応については，一点目として，技術点や価 格点に関する入札結果について可能な限り詳細に公表す ること，二点目として，過去の入札データを分析し，そ の結果を広く入札参加者に認知させることが考えられる 前者については，落札者の技術提案内容と他の入札者の 技術提案内容を比較整理したものや，技術提案の内容を 点数化したプロセスを公開することも考えられるが，技 術提案内容には各入札者のノウハウが記載されているた め，各入札者が独自に保有する技術情報を保護する観点 から困難であると考えられる．現状において，「予定技 術者の成績及び表彰」，「評価テーマ」等といった技術 評価点の内訳レベルの点数が入札後に公開されているが, 入札結果の公表はこのレベルが限界であるものと考えら れる，一方，後者については，業務内容によってその技 術点差の分布は大きく異なることが予想され，業務内容 毎の技術点分布を分析・公表することによって，入札者

表-3 聞き取り調査の結果

\section{(1)総合評価落札方式において調査基準価格近傍で入札する理由}

-過去の入札において，技術点 1 位が複数者存在したり，各入札者の技 術点差がわずかであったりするため.

•入札する時点で他の入札者との技術点差が不明であるため.

• 直轄事業における業務実績，表彰が少ない分を価格面で埋め合わせ るため.

·履行確実性評価実施業務において，低入札時の入札辞退が比較的 容易にできるようになったため

\section{(2)総合評価落札方式の評価方法として望まれるもの}

・技術提案書等の評価は, 極力、点数差が開くような方法をとるべきで ある。

•価格競争を緩和するためには, 価格と技術の評価に関する配点比率 をより技術重視とするべきである.

•技術評価点のうち, 業務成績や表彰の評価よりも技術提案書の評価 を重視するべきである

手持ち業務の受注額·件数を技術点の一部として採用するべきであ る.

は業務内容に応じて入札額を設定することがある程度可 能になるものと考えられる.

技術評価における業務実績や表彰の点数化に関しては, 過去の実績を評価することが新規参入を困難にし，一部 の技術者，事業者に業務が集中することが従前より受注 者側からのみならず発注者側からも懸念されている。こ れに対しては，関東地方整備局や中国地方整備局で発注 する一部の業務において手持ち業務量の点数化や技術者 表彰の点数化の廃止を実施しているところである. 今後 は，こうした地方整備局独自の取組の全国展開を見据え て，取組の結果に注視したい.

\section{4. 総合評価落札方式における技術評価について}

先述の受注者聞き取り調查における，競争各者の技術 点差が小さいために調査基準価格近傍へ入札が集中して いるとの意見を踏まえて，平成23年度に実施した総合評 価落札方式における技術点1位と2位の得点差を以下に整 理した.

\section{a) 結果}

総合評価落札方式における技術点1位と2位の差につい て，各得点差の業務件数割合を図-6に示し，各配点比率 における得点差の平均值を表-4に示寸，平均得点差は， 配点比率 $1 ： 2$ の場合が最も大きく5.58点となっている また，1：2においては5点以上差が開いている業務が 全体の37\%を占め，1：1の23\%，1：3の21\%に比し て大きい，一方で，1位と2位が同点である割合は，1： 3 が最も小さく，0\%となっている．全配点比率の半数 近くの業務において技術点1位と2位の差が3点以下とな っている. 
配点比率 $1: 1$

$\mathrm{N}=2,397$

$8 \%$

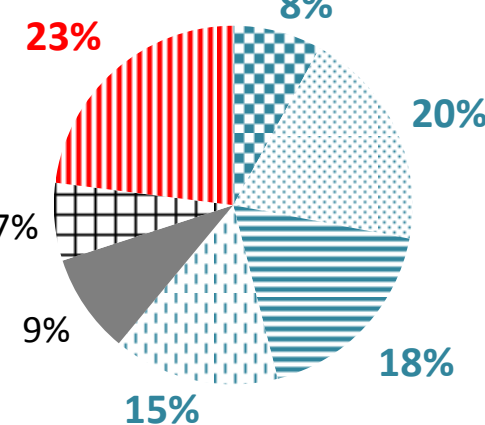

8 同点

3 点超4点以下
配点比率 $1: 2$

$\mathrm{N}=2,218$

$8 \%$

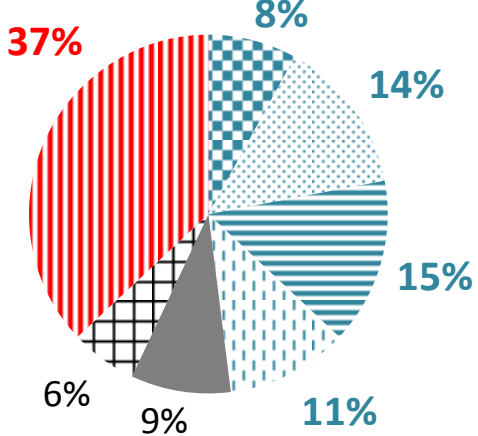

0点超1点以下 $\quad$ 1点超2点以下

井 4点超5点以下 $\quad||||$ 5点以上
配点比率 $1: 3$

$\mathrm{N}=71$

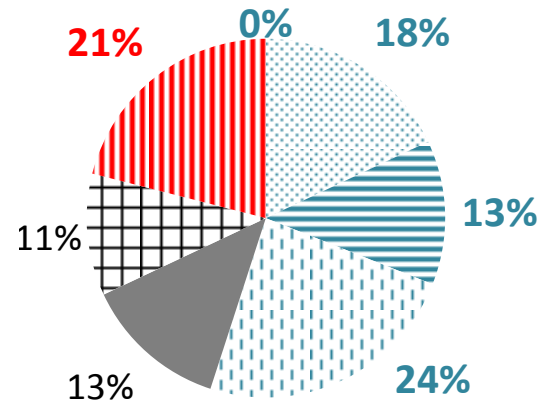

図-6 技術点1位と2位の得点差の割合(平成23年度) ${ }^{1)}$

表-4 配点比率別平均得点差 ${ }^{1)}$

\begin{tabular}{|l|c|c|c|}
\hline 配点比率 & $1: 1$ & $1: 2$ & $1: 3$ \\
\hline 平均得点差 & 3.61 & 5.58 & 3.82 \\
\hline
\end{tabular}

\section{b) 考察}

技術点が60点満点，価格点が20点満点～60点満点であ ることを考慮すると，全配点比率の半数近くにおいて， 技術点1位と 2 位の差が3点未満である現状は，入札者が 自身の技術力の優位性を価格に反映させることを躊躇さ せるものであると考えられる，仮に，配点比率が $1 ： 1$ の入札において，技術点1位と2位の入札者の得点差が2 点である場合，技術点 1 位の入札者は，技術点2位の入札 者の入札額に対して，僅か3\%程度しか入札額に上乗せ ができない，一方で，配点比率が $1 ： 3$ の入札において 技術点1位と2位の入札者の得点差が5点である場合，技 術点1位の入札者は，技術点2位の入札者の入札額に対し て，25\%の入札額の上乗せが可能である．入札者の技術 力を十分に入札額に反映させ，価格競争を緩和するため に，発注者側は技術点に差がより生じやすい配点や評価 方法を導入するとともに，配点比率を設定するに際に， より技術点の配点比率が高い $1 ： 2 ， 1 ： 3$ を極力採用 することが重要であると考えられる．地方整備局等にお いて配点比率を決定する際には，運用ガイドラインが 用いられているが，これによると，総合評価落札方式標 準型は $1 ： 2$ と $1 ： 3$ で実施され，評価テーマ(発注者 が業務毎に設定）に関する技術提案と業務の実施方針を 求めることとなっていることに対し，総合評価落札方式 簡易型は原則 $1 ： 1$ で実施され（限定的に $1 ： 2$ も実施 可能），技術提案として実施方針の提出のみを求めるこ ととなっている. 早期発注，受発注者負担軽減の観点か
らは，評価テーマに関する技術提案の提出がなく，手続 き期間が短い，簡易型の 1 ：1の方がメリットが大きく， より適用されやすいものと考えられる.

こうした中で，九州地方整備局においては独自の取組 として，平成25年度より，受発注者の負担を軽減し 1 ： 2，1：3の採用を促すことを目的として，従来，総合 評価落札方式簡易型のみでヒアリングの省略が可能であ った運用を，総合評価落札方式標準型においても省略で きるよう変更している．技術点を重視する観点からは， 当面の対策として有効であるとも考えられるが，ヒアリ ングの省略については，その妥当性について引き続き十 分な検討が必要である.

翻って，民間企業の発注事例を見ると，東日本高速道 路株式会社等の総合評価落札方式においては，価格競争 を緩和させるために，調査基準価格近傍における価格差 の評価点への影響を押さえるような評価值算定式を用い ているの.このような事例を参考に，価格点算定方法を 見直し，価格競争を緩和することも考えられる.

\section{5. まとめ}

本研究においては，国土交通省直轄事業の調査・設計等 業務において総合評価落札方式の導入状況について概観 し，低入札落札が減少する一方で，調査基準価格近傍に 入札額が集中し，価格競争が依然として緩和されない原 因について分析した。受注者からの聞き取り調査により， 調査基準価格近傍への集中の原因としては「競争者間に おいて技術点差が小さいこと」や，「自身の相対的な技 術点の位置を予測することができないこと」，「業務実 績や表彰など技術点における既定值の割合が大きいこ 
と」が指摘された。これを受けて，技術点における1位 と2位の点数差について分析を行ったところ，2割から4 割程度の業務において5点以上の点数差が生じているも のの，半数近くの業務において3点差以内の僅差である ことが判明した。

以上を踏まえ，今後は，技術点の差がなるべく生じる ような評価方法, 評価点算出方法を検討する必要がある ものと考えられる．また，業務によって技術点差が異な ることを認知させ，入札参加者が技術力を価格に反映さ せや寸くするために，業務の種別毎に平均技術点数差を 分析し公表する等，受注者に対する発注者からの情報提 供を積極的に行うことも重要である，今後は，受注者が 安心して技術力の優位性を価格に反映させることができ る入札手法について検討したい.

\section{参考文献}

1）一般財団法人日本建設情報総合センター：入札情報 サービス， http://www.i-ppi.jp/IPPI/SearchServices/Web/Index.htm

2) 調查・設計等業務に関する入札・契約の実施状況 （平成 23 年度年次報告書・詳細版），国土技術政策 総合研究所, 2013.

3) 森田康夫, 大谷悟, 吉田純土, 南昌宏 : 土木技術資 料 第 54 巻 第 12 号, pp. $50-53$, 一般財団法人土木
研究センター, 2012.

4）木下誠也：公共事業における建設コンサルタント業 務の調達方式に関する国際比較研究, 土木学会論文 集 F4（建設マネジメント），Vol. 68，No. 4，I_169I_179, 2012

5）建設コンサルタント業務等におけるプロポーザル方 式及び総合評価落札方式の運用ガイドライン, 調 査・設計等分野における品質確保に関する懇談会, 2011.

6) 東日本高速道路株式会社：工事における総合評価落 札方式及び低入札価格調査の改善について, 2012.

7) 木下誠也: 公共調達研究, pp.118-136, 日刊建設工業 新聞社, 2012.

8) 重高浩一, 溝口宏樹, 毛利淳二 : 総合評価方式によ る詳細設計業務等の入札に関する考察，第 25 回建設 マネジメント問題に関する研究発表・討論会講演集, 2007

9) 調查・設計等分野における品質確保に関する懇談会 資料, 国土交通省, 2013.

10）建設コンサルタント白書, 一般社団法人建設コンサ ルタンツ協会, 2012.

11) 國島正彦, 庄子幹雄 : 建設マネジメント原論, 山海 堂, 1997.

\section{A Study on the Quality and Cost Based Selection System which is Operated by Ministry of Land, Infrastructure, Transport and Tourism in the field of Construction Consultant Engineering}

\section{Jundo YOSHIDA, Yasuo MORITA, Satoru OTANI, Masahiro MINAMI, and Tomoyumi KOMIYA}

The dumping prevention system have greatly decreased the low price of successful biddings in the Quality and Cost Based Selection System(QCBS). On the other hand, many bidding prices are immediately above the threshold price for low price inquiry. Some possibilities emerged after the interviews with bidders. The reason of such bidder's action seems that many bidders didn't consider about capabilities of their own engneerings, when they decided the bidding price.

On this study,we review the latest trend of QCBS, and examine the recent problem of QCBS, that is way of evaluation approach about quality and price. 